\title{
Cell Imaging with Fluorescent Bi-Metallic Nanoparticles
}

Natalia Ye. Stasyuk ${ }^{a}$, Galina Z. Gayda ${ }^{a^{*}}$, Roman Ja. Serkiz ${ }^{a}$, Mykhailo V. Gonchar ${ }^{a, b}$

${ }^{a}$ Institute of Cell Biology, NAS of Ukraine, Drahomanov Str. 14/16, 79005 Lviv, Ukraine

E-mail address: stasuk_natalia@ukr.net

E-mail address: galina.gayda@gmail.com

E-mail address: rserkiz@gmail.com

E-mail address: gonchar@cellbiol.Iviv.ua

${ }^{\mathrm{b}}$ Institute of Applied Biotechnology and Basic Sciences, University of Rzeszow, Sokolowska Str. 26, 36-100 Kolbuszowa, Poland

*Corresponding author: galina.gayda@gmail.com

\begin{abstract}
Last decades various imaging techniques have been applied in biological and biomedical research, such as magnetic resonance imaging, different types of tomography, fluorescence/bioluminescence, ultrasound, as well as multimodality approaches. Fluorescence imaging, especially in combination with nanoscale materials, is a very prospective tool for experiments in vivo and clinical applications due to its high temporal and spatial resolutions. Fluorescent nanoparticles (NPs), having ability to interact with biomolecules both on the surface of and inside the cells, may revolutionize the cell imaging approaches for diagnostics and therapy. In our investigation we report about new method of cell imaging with fluorescent bi-metallic NPs synthesized by chemical reduction of the relevant ions. As the model of living organism, the cells of yeast Hansenula polymorpha were used. All NPs in minimal concentration (up to $0.05 \mathrm{mM}$ ) was proved to be nontoxic for yeast cells. The NPS and NPs-modified cells were characterized with the methods of UV-VIS spectroscopy, scanning electron microscopy, atom force microscopy, transmission electron microscopy and fluorescence microscopy. The bimetallic NPs, possessing the stable fluorescence in solution and inside the cells, allow to observe the phenomenon of NPs transferring from parental to daughter cells through at least three generations followed by releasing from the modified cells. The fluorescent NPs synthesized being small, non-toxic and fluorescent was shown to be perspective tool for cell imaging.
\end{abstract}

\section{Keywords}

Nanoparticles of noble metals - Fluorescence - Toxicity of nanoparticles - Yeast Hansenula polymorpha - Cell imaging .

\section{Academic Discipline And Sub-Disciplines}

Natural Products Chemistry

\section{SUBJECT CLASSIFICATION}

Chemistry Subject Classification

TYPE (METHOD/APPROACH)

Experimental Study-Analytical Method

\section{Council for Innovative Research}

Peer Review Research Publishing System

\section{Journal: Journal of Advances in Chemistry}

\author{
Vol. 11, No. 4 \\ editorjaconline@gmail.com
}




\section{INTRODUCTION}

Metal NPs, consisting of one metal, metal oxides or composite of several metals, have received much attention as a building block of advanced materials for nanoscience and nanotechnology, especially in various imaging techniques for medicine [1-8].

Metal colloids can be obtained through different physics-chemical methods [9-12] as well as wet chemistry methods and "green synthesis" [13-16]. The small size of NPs allows for sufficient mobility by Brownian motion and specificity in molecular interactions. Functionalized NPs of noble metals, having the strong optical absorption and fluorescence, can be applied as markers for microscopic investigation in cell biology as well as for detecting molecular interaction and labeling biochips [17-18].

Core-shell metal NPs possess unique optical, electronic, magnetic and catalytic properties [11, 17-20]. Binary silver and gold NPs can be used in particular for addressing different optical channels in the visible spectrum. The shift of the plasmonic band is affected by the ratio between contents of $\mathrm{Ag}$ and $\mathrm{Au}$, the shape and the size of the binary particles, and the distribution of the two metals inside the particle [21]. Thus, a different plasmon absorption is obtained if both of the metals are forming core/shell particles with $\mathrm{Au}$ (core)/Ag(shell), $\mathrm{Ag}$ (core)/Au(shell) or an ally [22-25].

NPs have large surface areas in comparison with bulk metals, and energy states are distinct, which results in a growth in fluorescence emission spectra [26-29]. The fluorescence emission spectra of $\mathrm{Au}(\mathrm{core}) / \mathrm{Ag}(\mathrm{shell})-\mathrm{NPs}$ were investigated and the quasistatic and local field theory describing the fluorescence emission property was developed [30]. This suggests that an interaction between two kinds of monometallic NPs make possible to produce novel NPs.

Fluorescent metal nanoclusters (FNCs) born a new class of fluorophores, very attractive due to their unique electronic structures and the subsequent unusual physical and chemical properties [4]. The size of metal NCs approaches the Fermi wavelength of electrons, between metal atoms and NPs, resulting in molecule-like properties including discrete energy levels, size-dependent fluorescence, good photostability and biocompatibility. These excellent properties make FNCs (mainly including $\mathrm{Au}, \mathrm{Ag}, \mathrm{Cu}$, etc.) ideal fluorescent probes for biological application with a look at the future challenges, especially for controllable drug delivery [4, 31-34].

However, many relevant issues remain open. These include the molecular mechanisms governing the NPs-cell interactions, the physics-chemical parameters underlying their toxicity to different types of cells, the lack of standard methods and materials, and the uncertainty in the definition of general strategies to develop effective chips and devices based on NPs [35-41].

In this paper we describe the simple procedures of synthesis and characterization of NPs of noble metals, their influence on living cell and demonstrate the perspectives of NPs application. As result of investigation, a new method of cell imaging with fluorescent NPs on the model of yeast cell was proposed.

\section{EXPERIMENTAL PROCEDURES}

\subsection{Chemicals}

Tetrachloroauric acid trihydrate, sodium citrate, sodium borohydride, cetyltrimethyl ammonium bromide (CTAB), ascorbic acid, silver nitrate, D-glucose, sodium hydroxide, inorganic salts, chlorofom and Butvar solution B-98 were purchased from Sigma-Aldrich, USA. All buffers and standard solutions were prepared using the water purified by the MilliQ system (Millipore).

\subsection{Synthesis of nanoparticles}

Nanoparticles (NPs) and nanowebs (NWs) were synthesized by the reduction of metal ions from appropriate salts according to the known methods in our modifications [42-43]. Conditions of NPs and NWs synthesis are presented in the Table 1. NPs or NWs were collected by centrifugation under $10000 \mathrm{~g}$ for $40 \mathrm{~min}$ (Hettich Micro-22R centrifuge), washed with water and precipitated by centrifugation. Pellets were suspended in $0.2 \mathrm{~mL}$ of water and stored till exploitation at +4 $\stackrel{\circ}{\circ}$.

Table 1 Methods of chemical synthe sis of nanoparticles

\begin{tabular}{|c|c|c|}
\hline Type of NPs & Reaction mixture and conditions & $\begin{array}{c}\text { Color } \\
\text { of NPs }\end{array}$ \\
\hline AuNPs & $1.25 \mathrm{~mL} 1 \mathrm{mM} \mathrm{HAuCl}_{4}+\begin{array}{c}0.125 \mathrm{~mL} 38.8 \mathrm{mM} \text { trisodium citrate; stirring for } 5 \mathrm{~min} \\
\text { at } 100^{\circ} \mathrm{C}\end{array}$ & wine-red \\
\hline${ }^{*}$ AuNPs & $0.145 \mathrm{~mL} 58.5 \mathrm{mM} \mathrm{HAuCl}_{4}+10 \mathrm{~mL} 10 \mathrm{mMCTAB}$ stirring vigorously $+0.8 \mathrm{~mL}$ \\
& $\begin{array}{c}100 \mathrm{mM} \mathrm{sodium} \text { borohydride; } \\
\text { stirring for } 2 \mathrm{~h} \text { at } 20^{\circ} \mathrm{C}\end{array}$ & violet \\
\hline
\end{tabular}




\begin{tabular}{|c|c|c|}
\hline AuNWs & $\begin{array}{c}0.145 \mathrm{~mL} 58.5 \mathrm{mMHAuCl}_{4}+10 \mathrm{~mL} 10 \mathrm{mMCTAB} \text { stirring vigorously }+0.8 \mathrm{~mL} \\
100 \mathrm{mM} \text { sodium borohydride; } \\
\text { incubation without stirring for } 24 \mathrm{~h} \text { at } 20^{\circ} \mathrm{C}\end{array}$ & dark blue \\
\hline AgNPs & $\begin{array}{l}0.1 \mathrm{~mL} 150 \mathrm{mM} \mathrm{AgNO}_{3}+25 \mathrm{~mL} 30 \mathrm{mMD} \text {-glucose }+ \\
0.35 \mathrm{~mL} 50 \mathrm{~m} \mathrm{M} \mathrm{NaOH} \text {; stirring for } 20 \mathrm{~min} \text { at } 20^{\circ} \mathrm{C}\end{array}$ & dark yellow \\
\hline $\begin{array}{l}\text { Au-core/Ag-shell- } \\
\text { NPs }\end{array}$ & $\begin{array}{l}0.01 \mathrm{ml} 100 \mathrm{mM} \text { ascorbic acid }+0.5 \mathrm{ml} 10 \mathrm{mM} \mathrm{AgNO}_{3}+5 \mathrm{ml} 0.9 \mathrm{mM} \mathrm{AuNPs}+ \\
0.15 \mathrm{ml} 100 \mathrm{mM} \mathrm{NaOH} ; \\
\text { incubation without stirring for } 24 \text { h at } 20^{\circ} \mathrm{C}\end{array}$ & $\begin{array}{l}\text { dark } \\
\text { red }\end{array}$ \\
\hline $\begin{array}{l}\text { *Au-core/Ag-shell- } \\
\text { NPs }\end{array}$ & $\begin{array}{l}0.01 \mathrm{ml} 100 \mathrm{mM} \text { ascorbic acid }+0.5 \mathrm{ml} 10 \mathrm{mM} \mathrm{AgNO}_{3}+5 \mathrm{ml} 0.9 \mathrm{mM}^{*} \mathrm{AuNPs}+ \\
0.15 \mathrm{ml} 100 \mathrm{mM} \mathrm{NaOH} ; \\
\text { incubation without stirring for } 24 \mathrm{~h} \text { at } 20^{\circ} \mathrm{C}\end{array}$ & violet \\
\hline $\begin{array}{l}\text { Ag-core/Au-shell- } \\
\text { NPs }\end{array}$ & $\begin{array}{c}10 \mathrm{ml} 0.25 \mathrm{mMHAuCl}_{4}+0.5 \mathrm{ml} 100 \mathrm{mMCTAB}+ \\
0.05 \mathrm{ml} 100 \mathrm{mM} \text { ascorbic acid; vigorous mixing for } 1 \mathrm{~min} \text {, followed by adding } 5 \mathrm{ml} \\
3 \mathrm{mMAgNPs} \text { and } \\
\text { incubation without stirring for } 24 \mathrm{~h} \text { at } 20^{\circ} \mathrm{C}\end{array}$ & violet \\
\hline $\begin{array}{l}\mathrm{Ag} \text {-core } /{ }^{*} \mathrm{Au} \text {-shell- } \\
\text { NPs }\end{array}$ & $\begin{array}{c}10 \mathrm{ml} 0.25 \mathrm{mM} \mathrm{HAuCl}_{4}+0.5 \mathrm{ml} 100 \mathrm{mMCTAB}+ \\
0.05 \mathrm{ml} 100 \mathrm{mM} \text { ascorbic acid; vigorous mixing for } 1 \mathrm{~min} \text {, followed by adding } 10 \\
\mathrm{ml} 3 \mathrm{mM} \mathrm{AgNPs} \text { and } \\
\text { incubation without stirring for } 24 \mathrm{~h} \text { at } 20^{\circ} \mathrm{C}\end{array}$ & red \\
\hline
\end{tabular}

\subsection{Cells}

The recombinant yeast strain Hansenula polymorpha NCYC 495-pGAP1-HsARG1-(leu2car1 Sc:LEU2), constructed in the Institute of Cell Biology, NAS of Ukraine, was used in investigation [42]. The cells of this strain (further - cells), over-express the HsARG1 gene, coding for human liver arginase I (further - arginase). These cells were applied in our experiments as the model of living organism.

Cultivation of the cells was performed in Erlenmeyer's flasks (volume $500 \mathrm{ml}$ ) as described earlier [44]. $110 \mathrm{ml}$ of liquid media in flask were inoculated by cells from the early stationary growth phase in concentration of $50 \mu \mathrm{g} / \mathrm{mL}$. Yeast cells for inoculation were taken from plates with agar Burkholder medium.

The grown cells were separated by centrifugation and washed twice with $30 \mathrm{mM}$ phosphate buffer, $\mathrm{pH} 7.5$ (PB). Activity of arginase in cell-free extracts of disrupted cells was detemined in a two-step reaction: 1) enzymatic conversion of L-arginine to ornithine and urea and 2) photometric registration of urea content by the colorimetric method [42].

\subsection{Interaction of nanoparticles with cells}

To study cellular toxicity of NPs synthesized, cells were grown in the presence of NPs in solid and in liquid media (see 2.3). For this aim aliquot of fresh-grown cell's suspension $(0.1 \mathrm{~mL}$, with concentration $5 \mu \mathrm{g} / \mathrm{mL}) \mathrm{was} \mathrm{put}$ on plate with agar. Each plate $(\mathrm{d}=85 \mathrm{~mm})$ contained agar supplemented by different NPs in various concentrations. Plates were incubated at $30^{\circ} \mathrm{C}$ during 3 days and tested visually on cells growth.

To modify by different NPs, the cells after 1 day cultivation in liquid medium (to the biomass about $3 \mathrm{mg} / \mathrm{mL}$ ) were supplemented with NPs till the concentration of $0.05 \mathrm{mM}$ (calculated on noble metal content) and were incubated for 4 days. As the control, cells incubated in medium without NPs were used. Aliquots of cell's suspension were taken every day during experiment and fractionated by centrifugation. Both pellet and supernatant as well as initial NPs were analysed by UV-VIS spectroscopy on Shimadzu UV-1650 PC spectrophotometer. Colloids of NPs and suspensions of NPs-modified cells were imaged by microscopic methods, described below. Each experiment was performed in triplicate and repeated at least three times.

\subsection{Microscopic imaging}

\subsubsection{Atomic Force Microscopy (AFM)}

The size and structure of NPs were studied by atomic force microscope Solver P47-PRO (NT-MDT). An aliquot of the tested sample was spread on the surface of freshly-cleaved mica, dried and analyzed in air using the tapping mode with a resonance frequency of $160 \mathrm{kHz}$, scan rate of $1 \mathrm{~Hz} / \mathrm{s}$ and resolution of $256 \times 256$ pixels. 


\subsubsection{Scanning electron microscopy (SEM)}

A Scanning Electron Microscope (SEM-microanalyser REMMA-102-02, Sumy, Ukraine) was used for morphological analyses of samples on a graphite rod (thickness $-0.5 \mathrm{~cm}$, diameter $-0.5 \mathrm{~cm}$ ). The special cover film on the samples with a Butvar solution B-98 (Sigma, St. Louis, MO, USA) in 1.5\% chloroform was formed using an ultrasound method. In experiments the distance from the last lens of the microscope to the sample (WD) ranged from $17.1 \mathrm{~mm}$ to $21.7 \mathrm{~mm}$; the accelerator voltage was in the range from 20 to $40 \mathrm{eV}$; zooms were from 2500 to 10000 .

\subsubsection{Fluorescence microscopy (FM)}

An inverted fluorescence microscope (Axio Lab. A1., Carl Zeiss, Germany) with excitation by a mercury vapor arc lamp (X-Cite series 120Q) was used for samples imaging. The filters set was composed by Fluorescein isothiocyanate (FITC), 4', 6-Diamidino-2-phenylindole (DAPI), Texas Red and Cyanine 5 azide (Cy5). To prepare testing sample, an aliquot $10 \mu \mathrm{L}$ of water-diluted probe was placed on a glass slide and covered with cover-slip (12 mmdiameter).

\subsubsection{Transmission electron microscopy (TEM)}

NPs analysis was carried out as described earlier [42]. For the cells analysis, samples were fixed in $1.5 \%$ aqueous solution of $\mathrm{KMnO}_{4}$ for 20 min at room temperature followed by post-fixation with $1 \%$ OsO $\mathrm{O}_{4}$ cacodylate buffer for $90 \mathrm{~min}$ at $0{ }^{\circ} \mathrm{C}$. The samples were dehydrated by mixing with corresponding solutions containing increasing concentrations of ethanol with final incubation in acetone. Samples were embedded in Epon 812. Ultrathin sections were sliced in an ultramicrotome UMTP-6 (Sumy, Ukraine) contrasted with lead citrate and examined with electron microscope PEM-100 (Sumy, Ukraine) at $75 \mathrm{kV}$. The final magnification of the micrographs was 10000.

\section{RESULTS AND DISCUSSION}

To develop a new method of cell imaging, we have carried out the following tasks: to synthesize NPs of noble metals; to study toxicity of these NPs on the model of yeast cell; to screen fluorescence ability and to test a storage stability of the synthesized NPs both in solution and inside the cell.

\subsection{Study of the synthesized particles with SEM and XRM}

In our study mono (Au, $\mathrm{Ag}$ ) and bi-metallic ( $\mathrm{Au} / \mathrm{Ag}$ and $\mathrm{Ag} / \mathrm{Au}$ ) NPs were synthesized with the simple chemical methods as described in 2.2 .

To characterize the synthesized NPs, the methods of scanning electron microscopy (SEM) with X-rav Microanalysis (XRM), atom force microscopy (AFM), UV-VIS spectroscopy and fluorescence microscopy (FM) were applied. The results of these experiments should let us find out whether the synthesized product is really nano -sized?

To get the quick estimation of the sizes metallic particles synthesized and to study their composition, SEM micros copy and XRM analysis were done.

As described earlier [42-43], the average diameters $\left(d_{a v}\right)$ of all monometallic NPs and AuNWs estimated by SEM are about $100 \mathrm{~nm}$. XRM data of these NPs proved the forming of $\mathrm{Au}^{0}$ and $\mathrm{Ag}^{0}$ compounds, with characteristic peaks $\mathrm{Ka}$ at $2.1 \mathrm{keV}$ and $3.0 \mathrm{keV}$, respectively.

$d_{a v}$, estimated with SEM for the freshly-synthesized bi-metallic NPs, are about $100 \mathrm{~nm}$, too (data not shown). The XRM image of Au/AgNPs (Figure 1) confirms the presence of $\mathrm{Ag}^{0}$ and $\mathrm{Au}^{0}$, proving the formation of both $\mathrm{AgNPs}$ and AuNPs, respectively. After 21 -day storage intensity of the $\mathrm{Au}^{0}$ peak decreased while the $\mathrm{Ag}^{0}$ peak got higher, probably as a result of AuNPs masking under shell of AgNPs (Figure 1). Thus, the XRM data confirmed the formation of the core/shell bi-metallic NPs, namely, Au(core)/Ag(shell).

The XRM images of the Ag/AuNPs show the characteristic peaks for $\mathrm{Ag}^{0}$ and $\mathrm{Au}^{0}$ indicating the formation of both AgNPs and AuNPs (Figure 1). After 21 days of the storage the ratio of $\mathrm{Ag}$ and Au peaks changed in comparison with fresh-prepared bi-metallic NPs. The specific for $\mathrm{Ag}^{0} \mathrm{Ka}$ peak became higher, indicating the full coverage of AuNPs with AgNPs. Thus, the XRM data confirmed the formation of the Ag (core)/ Au (shell) NPs.

The stability of colloids was reported to enhance after coating them with noble metal NPs [20, 30, 45]. According to the SEM and XRM data, during 21 days of storage, the synthesized Au/AgNPs was shown to be satisfactory stable. At the same time, $d_{a v}$ of Ag/AuNPs increased to $500 \mathrm{~nm}$ as result of aggregation of the synthesized Ag/AuNPs.

Thus, we suggest the simple methods of two-step chemical reduction of ions from appropriate inorganic salts for the obtaining of core/shell bimetallic NPs (see Table 1). The proposed app roach may be us eful for obtaining of different novel core-shell structured bi-metallic and three-metallic NPs. 

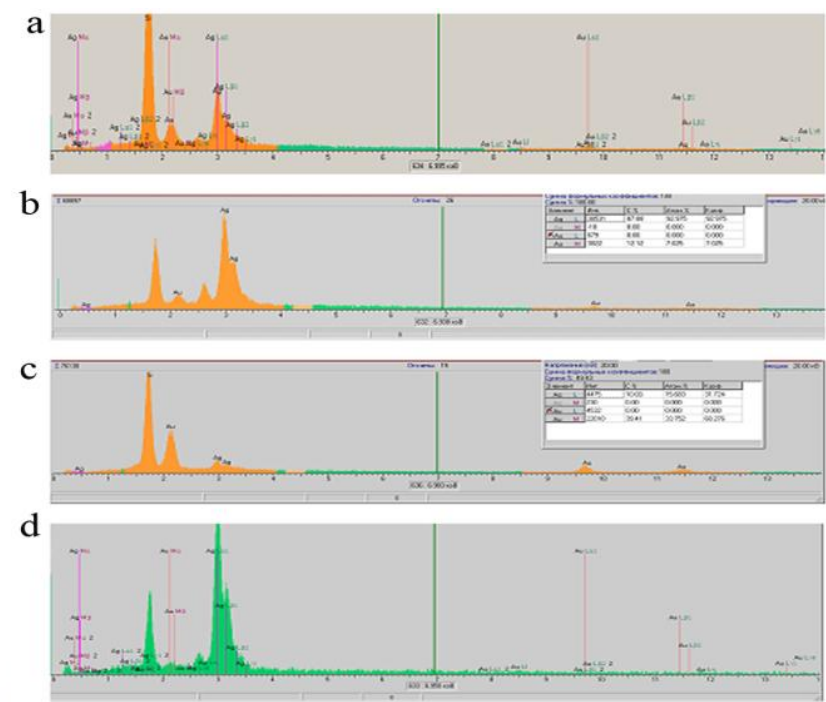

Figure 1: X-ray-spectral characteristics of bi-metallic NPs after 1st $(a, c)$ and $21 s t(b, d)$ days of the storage at $+8{ }^{\circ} \mathrm{C}$ : Au/AgNPs (a, b) and Ag/AuNPs (c, d).

\subsection{Characterization of the NPs with AFM}

To estimate the exact sizes and to study the morphology of the NPs synthesized, methods of TEM, powder XRD analyses and AFM were applied as described earlier [35]. The average diameters of AuNPs and AgNPs were shown to be less than $20 \mathrm{~nm}$ and diffraction peaks parameters of these NPs can be perfectly indexed into the cubic crystalline structures. The crystallite sizes were calculated from the main diffraction peaks as described earlier: for AuNPs $d_{a v}$ is $8.1 \mathrm{~nm}[42]$ and for AgNPs $-17.0 \mathrm{~nm}$.

Figure 2 shows AFM images (a-b) and Gaussian distribution by size (c) of the synthesized Au/AgNPs and $\mathrm{Ag} / \mathrm{AuNPs}$ in comparis on with AuNPs [42]. The mophology of the AuNPs $\left(\mathrm{d}_{\mathrm{av}}=16 \mathrm{~nm}\right)$ was shown to be almost smooth and their surfaces were homogeneous (Figure 2-1). In case of both bi-metallic NPs, the values of $d_{a v}$ were not higher than 20-25 nm, but their surfaces were rather heterogeneous (Figure2-2,3) as a result of NPs aggregation. Still some of the tested bi-metallic NPs did have bigger $d_{a v}$, the largest of them was estimated to be $160 \mathrm{~nm}$.

$1 \mathrm{a}$

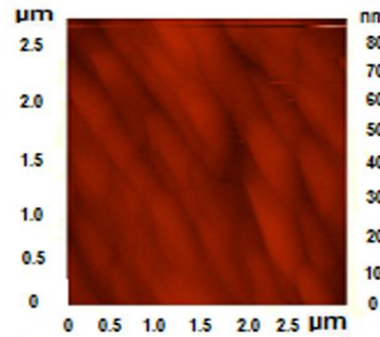

$2^{a}$
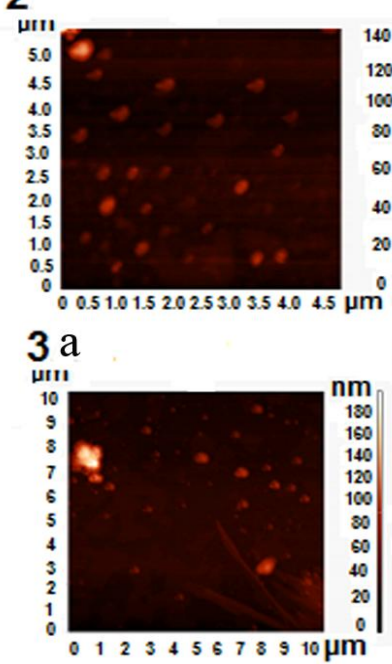

\section{$1 \mathrm{~b}$}

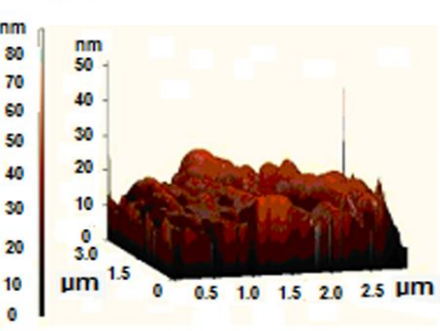

$2 \mathrm{~b}$

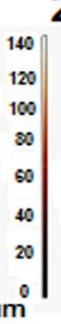

$3 \mathrm{~b}$

$3 \mathrm{C}$
$1 \mathrm{c}$

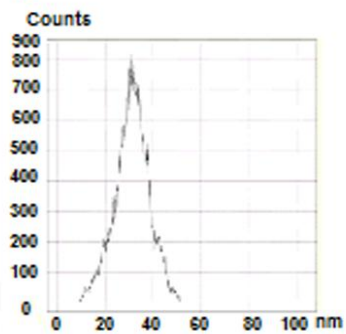

$2 \mathrm{C}$
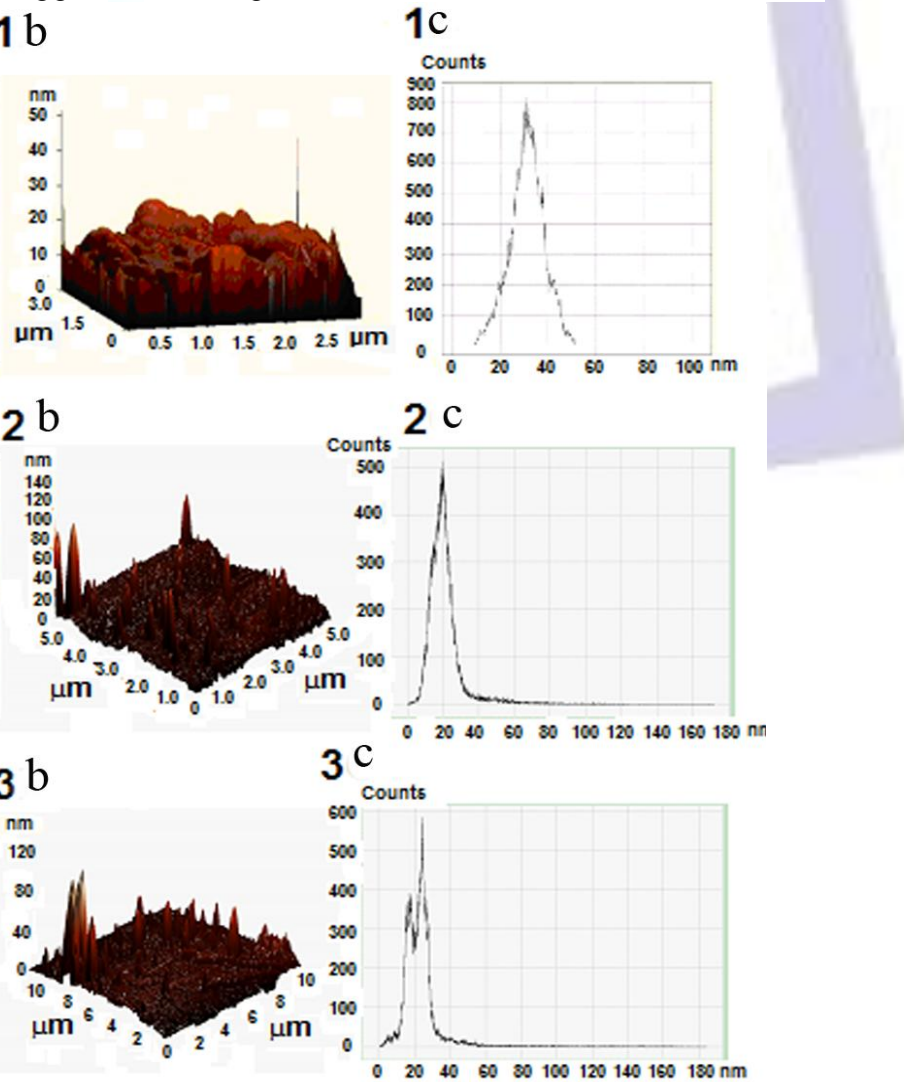

Figure 2: AFM micrographs (a,b) and Gaussian distribution by size (c) of AuNPs (1), Au/AgNPs (2) and Ag/AuNPs (3) 


\subsection{Optical properties of the NPs}

UV-VIS absorption spectra was shown to be quite sensitive to formation of metallic colloids [23, 30]. The synthesized NPs of noble metals exhibited intense absorption peaks, as the result of the surface Plasmon excitation, of yellow, red, orange and violet colours (see Figure 3 and Table 1).

The fresh-synthesized monometallic AuNPs and AgNPs (after 1-day storage at $+4^{\circ} \mathrm{C}$ ) show intensive plasmonic absorption bands at $525 \mathrm{~nm}$ and $410 \mathrm{~nm}$, respectively (see Figure $3 \mathrm{a}, \mathrm{b}$ ), that are typical for the corresponding NPs [19, $23,30]$. The stability of monometallic NPs during 21 days is satisfactory according to UV-VIS study (Figure 3 a, b). On the contrary, the spectra of the AuNPs and AgNPs, kept during 3 weeks, demonstrated sharper and higher peaks of corresponding NPs, than the initial ones of the fresh-prepared nanocolloids. These changes may be explained, probably, by formation of nano-crystals of AuNPs and AgNPs (according to XRD-data).

The characteristics of metal NPs was shown to be altered by the addition of other metals [20, 45]. The wavelength of the absorption peak can be tuned if $\mathrm{Ag}$ and $\mathrm{Au}$ are integrated in binary metal NPs $[11,18,20]$.

Plasmonic-based colour switches proved to be affected by the ratio between $\mathrm{Ag}$ and $\mathrm{Au}$, the shape and the size of the binary NPs, and the distribution of the two metals inside the particle [46]. In case of thickness-controlled synthesis of core-shell structured NPs, the surface condition of the outer metal can be tuned as a function of the inner metal surface, provided that the outer shell is thin enough [32]. In our study we demonstrated, that if the AuNPs were coated with $\mathrm{Ag}$ under $\mathrm{Au}$ (core)/Ag(shell)NPs formation (see Figure $3 \mathrm{~d}$ ), the absontion band would shift the solution changed from red to orange. As contrast, covering AgNPs with AuNPs resulted in change of the solution's colour from yellow to violet. The plasmonic absorption for $\mathrm{Ag}$ (core)/Au(shell)NPs is dominated by Au and shifts from $410 \mathrm{~nm}$ to $590 \mathrm{~nm}$ (Fig ure $3 \mathrm{c}$ ). The shift of absorption bands at much higher wavelengths (from 525 to $590 \mathrm{~nm}$ for hybride NPs with dominated AuNPs) may be explained by formation of larger than initial or non-spherical NPs [8, 17, 47-48]. The absorption peaks specific for Au/AgNPs change drastically during 21 -day storage from $395 \mathrm{~nm}$ and $495 \mathrm{~nm}$ to $385 \mathrm{~nm}$ and $505 \mathrm{~nm}$, respectively (Figure $3 \mathrm{~d}$ ). These changes may be explained by nano-crys tals formation.
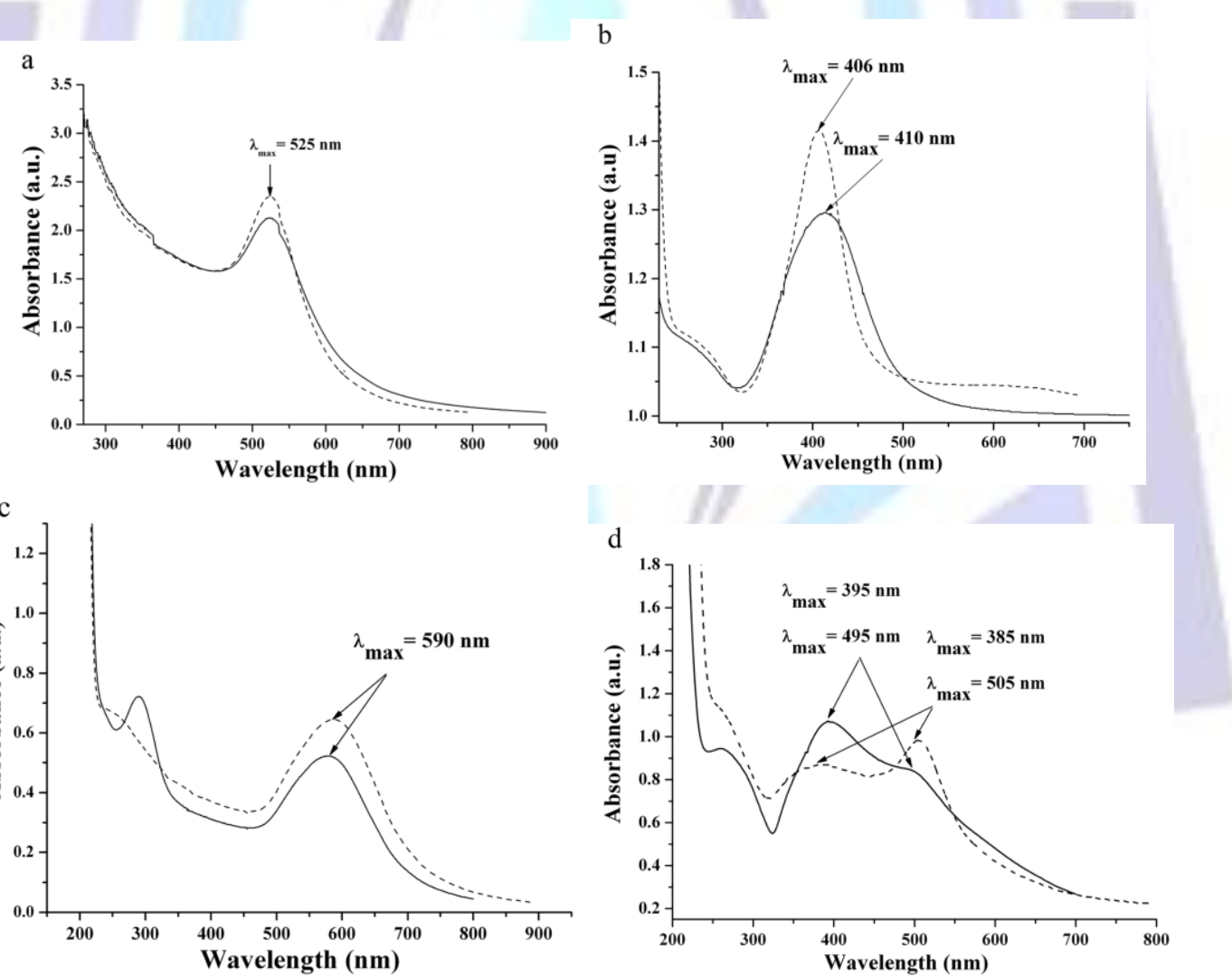

Figure 3: Absorption spectra of AuNPs (a), AgNPs (b), Ag/AuNPs (c) and Au/AgNPs (d); stability of NPs after storage during 1 day (solid) and 21 days (dashed).

\subsection{Fluorescence properties of NPs}

Fluorescence imaging is a very important technique for biological studies in vivo and clinical applications due to its high temporal and spatial resolutions. An inverted fluorescence microscope (FM) system allow to investigate the laser excited emission of the synthesized NPs.

The results of NPs analyses with FM are demonstrated in Figures 4-5. All fresh-prepared NPs investigated proved to be spherical in shape (Figure4). All NPs emit blue light, but only bimetallic NPs have additional bright 
fluorescence: Ag/AuNPs emit light in green channel (FITC filter); Au/AgNPs - in red (Texas Red filter) and in infra-red (Cy5 filter) channels. The storage stability of NPs in water was more than 2 months at $+8^{\circ} \mathrm{C}$.

The storage of bi-metallic NPs during 2-3 weeks in initial solutions of reagents without mixing was followed by nanowebs (NWs) formation (Figure5 and Table 1).

Thus, the covering of core NPs by the shell of noble metals make these stable fluorescent bi-metallic NPs attractive for biomedical application.

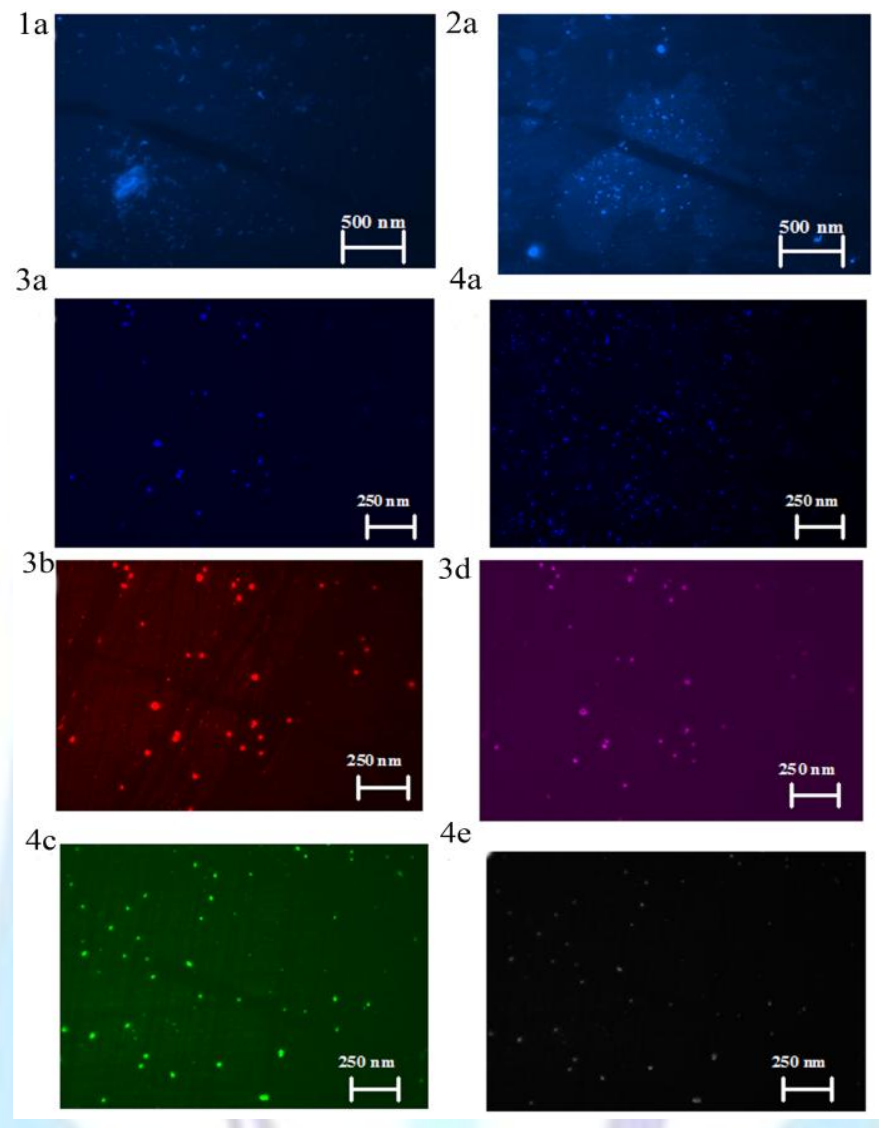

Figure 4: The fluorescence images of the fresh-prepared NPs: AuNPs (1); AgNPs (2); Au/AgNPs (3) and Ag/AuNPs (4) on different filters: a - DAPI (blue); b - Texas Red (red); c-FITC (green); d - Cy5 (infra-red) and e - brightfield

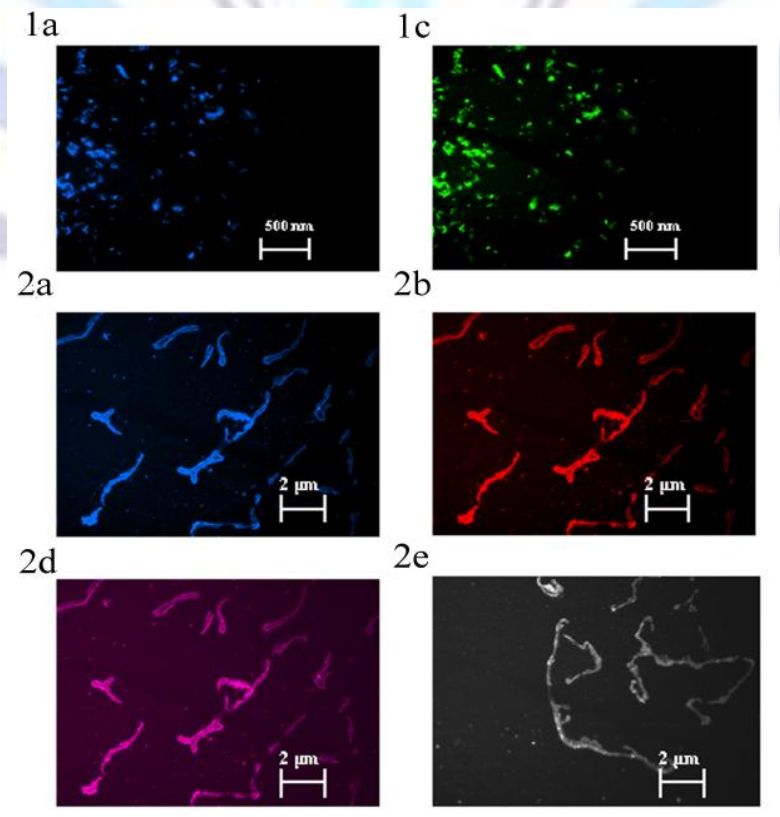

Figure 5: The fluorescence images of Ag/AuNPs (1) and *Au/AgWs (2), that were kept during 2 weeks without stirning Channels: $a$ - blue; $b$ - red; c-green; $d$ - infra-red and e - brightfield. 


\subsection{Development of a cellular imaging method with fluorescent NPs}

The number of imaging techniques have been applied in biological and biomedical research last decades, such as magnetic resonance imaging, computed tomography, positron emission tomography, single-photon emission computed tomography, fluorescence/bioluminescence, ultrasound, as well as multimodality approaches. With the size comparable to biological molecules, but orders of magnitude smaller than human cells, NPs can offer unprecedented interactions with biomolecules both on the surface of and inside the cells which may revolutionize disease diagnosis and treatment [6].

\subsubsection{Interaction of cells with NPs}

The cells of the yeast $H$. polymorpha (further - cells) were used in our investigations as the model of living organism for study of toxicity of NPs and possibility of cellular imaging with fluorescent NPs. In order to study the possible toxic effects of the NPs synthesized, microbiological experiments were performed: cells were grown in the presence of NPs with different concentrations in agar plates as well as in a liquid medium. According to our results, all the synthesized NPs added to described agar medium at low concentration (from 0.01 to $0.05 \mathrm{mM}$ ) proved to be non-toxic for cells (data not shown).

To collect and characterize the cells that interacted with $0.05 \mathrm{mMNPs}$, the living cells, preliminary inoculated for 2 days, were incubated in liquid media with different concentration of NPs during 5 days under shaking. As the control, cells without NPs were grown. Aliquots of cells were taken every day and analysed.

NPs interaction with cells was tested visually and by UV-VIS spectrophotometry. The colour of these cells changed in comparison with the control ones as result of NPs accumulation inside the cells (Figure6). At the same time, the spectra of the corresponding supernatants demonstrated a drop in NPs' concentration (data not shown). Thus, NPs modified cells (further - cell-NPs) are formed as a result of the interaction between cells and NPs.

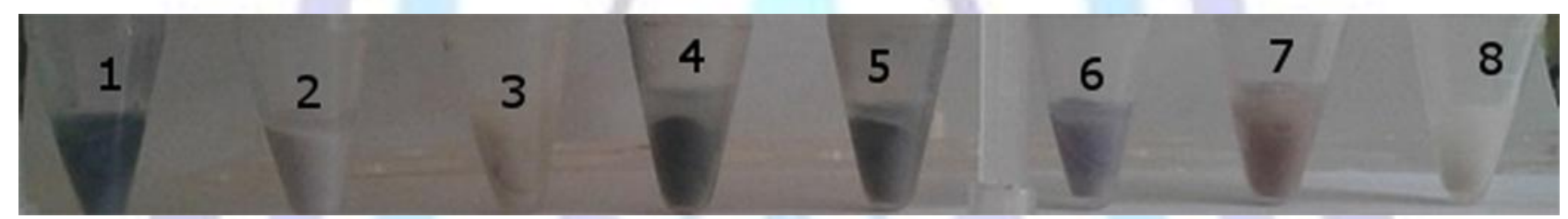

Figure 6: Pellets of the cells enriched with NPs (marked as described in Table 1), added to cells up to $0.05 \mathrm{mM}$ : *AuNPs (1), AuNPs (2); AgNPs (3); Au/AgNPs (4), *Au/AgNPs (5), Ag/AuNPs (6), *Ag/AuNPs (7) and the control cells (8)

To provide the detailed analys is of cell-NPs, the methods of SEM with XRM, TEM and FM were applied. The results of these investigations can give us answers to the following questions: are the NPs located inside or on the surface of the cell? Do these NPs maintain the fluorescence ability inside the cell and how long does it continue? Are the cellsNPs alive? Is the transport of NPs to the cells reversible? How many generations are necessary to release the cells -NPs from NPs?

\subsubsection{Localization of NPs in cells}

The SEM images with XRM analys is of the cells-NPs demonstrated that NPs are not located on the surface of these cells (Figure 7).
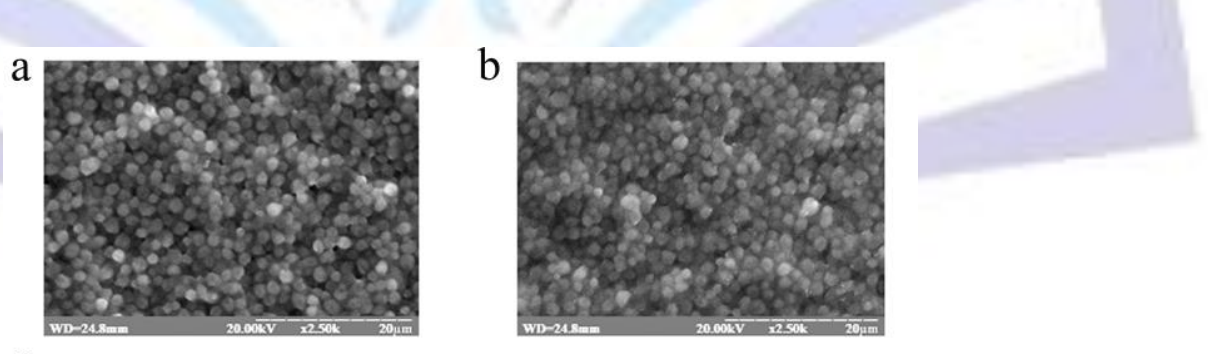

C

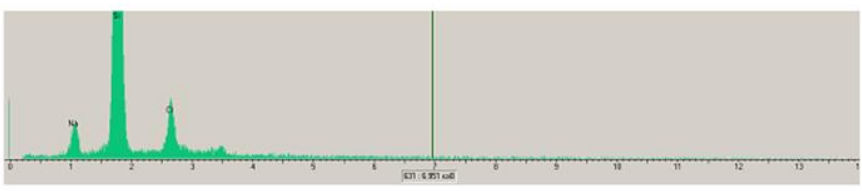

Figure 7: SEM of native cells before (a) and after (b) enrichment with AuNPs; X-ray spectral analysis of cells-AuNPs (c)

Only after cells-NPs permeabilization or disruption with glass beards, NPs were detected with XRM analysis (data not shown). These results suggest the presence of NPs inside the cell. The data of TEM analysis (Figure 8 ) prove this assumption. 
a

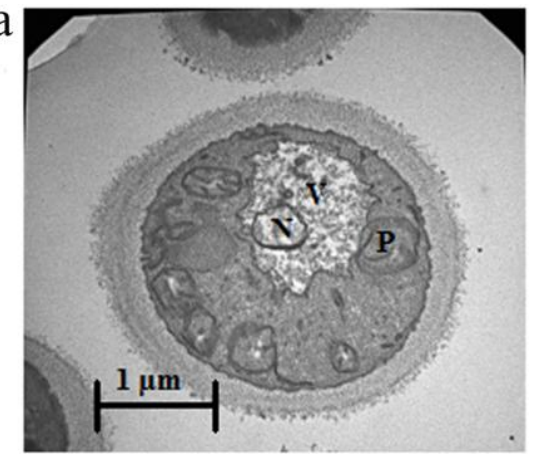

b

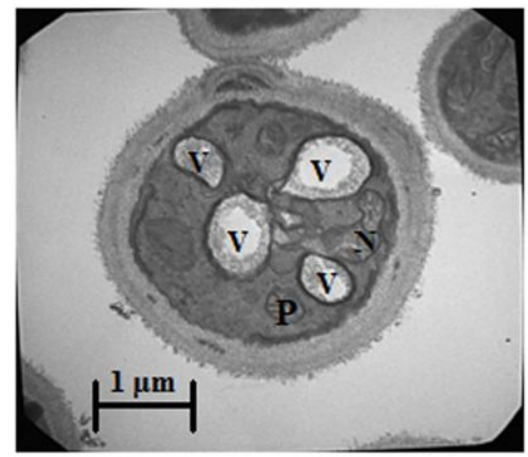

Figure 8: TEM of cells: control cells (a); after one day exposition to AuNPs (b). P - peroxisome, N - nucleus; V vacuole. Scale bar $-1 \mu \mathrm{m}$.

After penetration inside the cell NPs are localized mainly in vacuoles. The increase of incubation time of NPs with the cells leads to the formation of a number of vacuoles, probably, as result of the cell's response to the impact of the NPs (Figure 6). This process, probably, plays an important role in neutralization of the toxic effects of NPs inside the cell.

The average diameter of vacuole increased twice comparing to control cell. The cytoplasm of the yeast is homogeneous and in normal cells it contains from one to three vacuoles of different sizes. When exposed to stress conditions caused by NPs, yeast cells divide their large vacuoles into numerous smaller ones, probably, to activate NPs uptake due to increasing the surface-to-volume ratio of the organells.

It is worth mentioning, that the modification of the cells with NPs takes part not only "in vivo", under cultivation conditions, but also "in vitro", when the cell's suspension in buffer is mixed with metal colloid. After storage of this suspension at $+8{ }^{\circ} \mathrm{C}$ without mixing, the colour of cells changed. The XRM data also proved the fact of NPs' uptake by the cells.

\subsubsection{Fluorescence of the cell-NPs}

To study the fluorescent properties of NPs inside the cell, aliquots of cells-NPs were taken and analysed at different stages of incubation.

Figure 9-11 demonstrate FM images of different variants of cell-NPs ("first generation" of the cells): bi-metallic NPs kept unique fluorescent ability being included inside the cells -NPs. The cell-NPs glow brightly on different filters during 3-4 days under incubation. The highest brightness of fluorescence was picked on the $2^{\text {nd }}$ and 3 rd days of the cells incubation with bi-metallic NPs. At the same time, mono-metallic NPs reveal no fluorescence inside the cells (Figure 11).

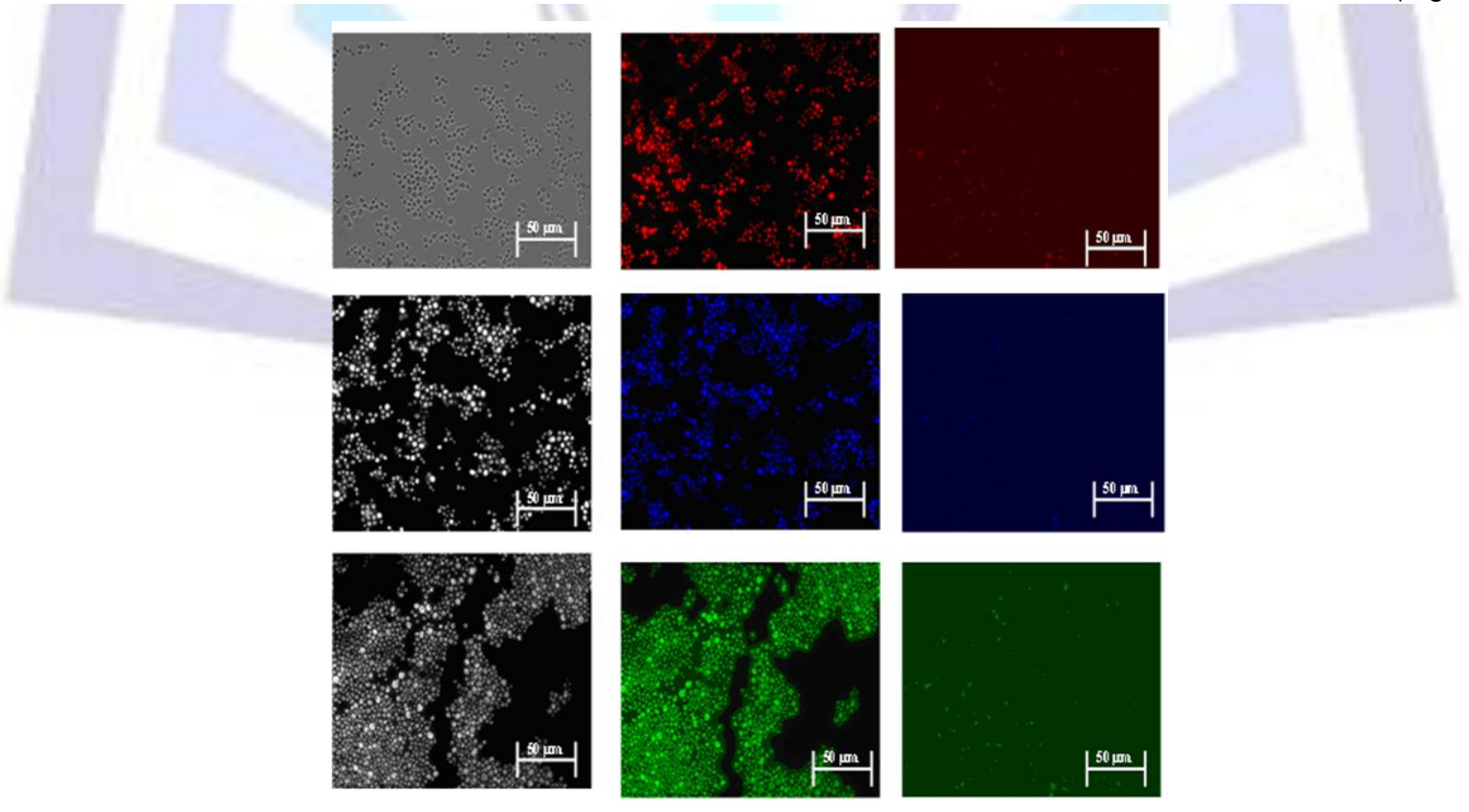

Figure 9: Fluorescent microscopy of 3-day incubated cells-Au/AgNPs (left and middle columns) in comparis on with control cells (right column) on different filters. Left column - brightfield light. Channels (from top to bottom): red, blue and green, respectively. Duration - $665 \mathrm{~ms}$. 

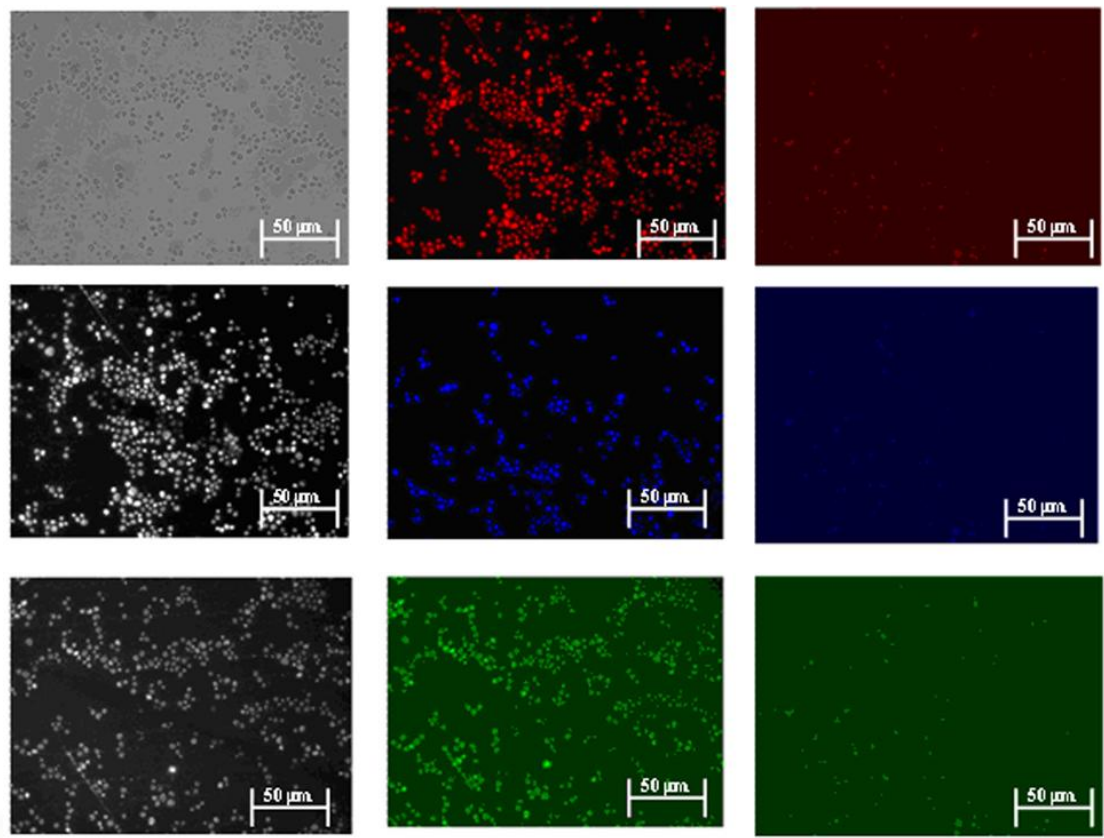

Figure 10: Fluorescent microscopy of 3 day cells-Ag/AuNPs (left and middle columns) in comparison with control cells (right column) on different filters. Left column - brightfield microscopy. Channels (from top to the bottom): red, blue and green, respectively. Duration - $665 \mathrm{~ms}$.

a
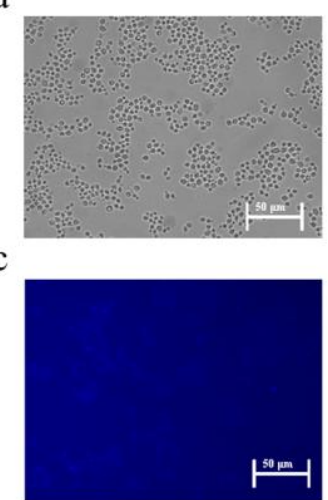

b

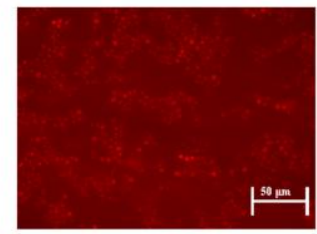

d

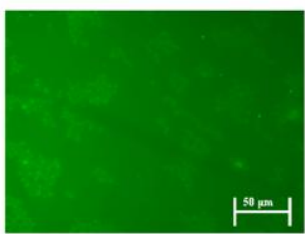

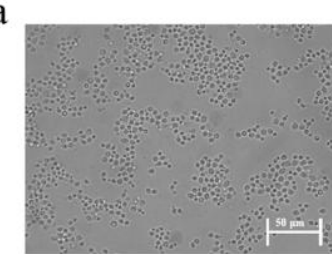

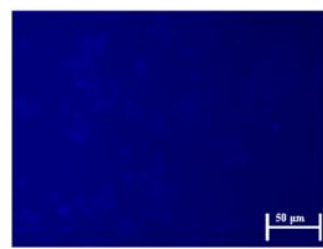

b
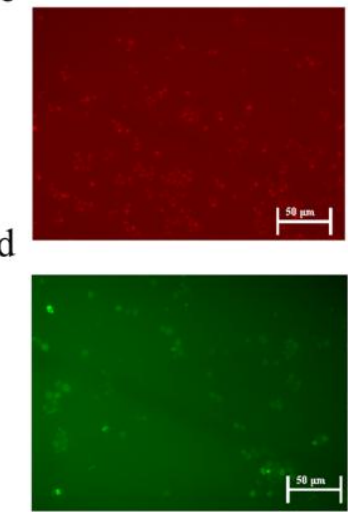

Figure 11: Fluorescent microscopy of the cells enriched with AgNPs (left) and AuNPs (right) during 3 days. Channels: brightfield (a), red (b), blue (c) and green (d). Duration $-665 \mathrm{~ms}$.

\subsubsection{Living ability and fluorescence stability of cells-NPs}

The cells-NPs were found to be alive after different NPs penetration: being incubated during several days in liquid medium with $0.05 \mathrm{mMNPs}\left(1^{\text {st }}\right.$ generation (Figure 12). Moreover, the activity of arginase (as a model of enzyme) in cell-free extracts of all tested cells-NPs didn't differ drastically from the one in control cells (data not shown). The cells NPs were tested on fluorescence ability being re-cultivated during 4 generations in solid agar as well as in liquid medium. FM experiments demonstrated the reduction of fluorescence in the living cells from the $1^{\text {st }}$ to the $4^{\text {th }}$ generations and, at the same time, the appearance of fluorescent bi-metallic NPs outside the cells of the $3^{\text {rd }}$ generation (Figure 12). According to the TEM images (Figure 12), NPs were released from these cells.

NPs uptake by cells was reported to depend on the composition, size and concentration of NPs as well as experiments conditions [37-39]. It is worth mentioning that if 2-day incubated cells-NPs of the $1^{\text {st }}$ generation were collected by centrifugation and frozen at $-20^{\circ} \mathrm{C}$, the fluorescence of these cells-NPs was preserved during at least 1 month. Thus, the NPs synthesized have unique characteristics being small, non-toxic and fluorescent, so, they may be perspective tool for cell imaging. 
a

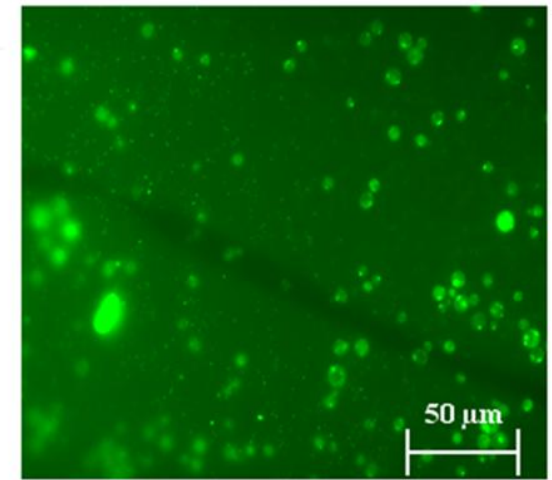

a

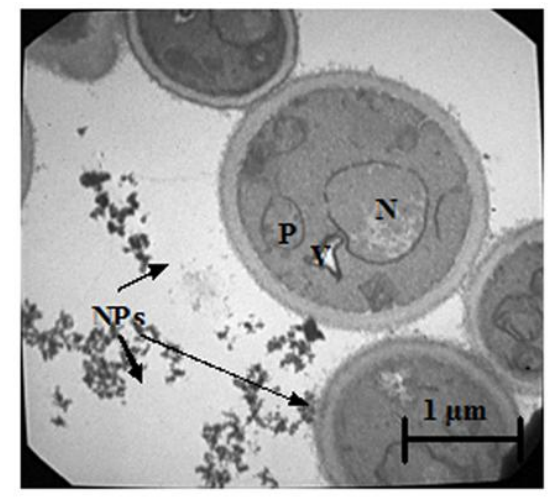

b

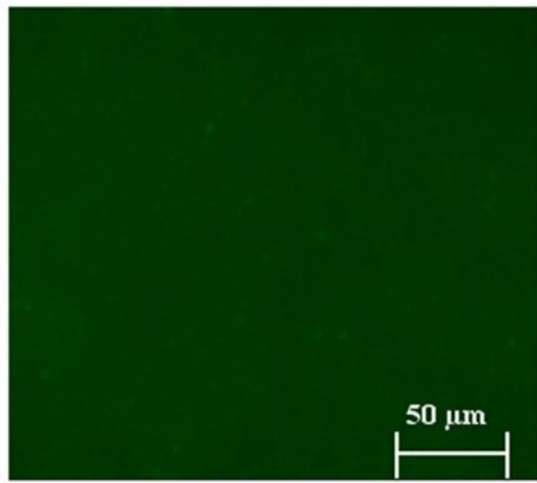

$\mathrm{b}$

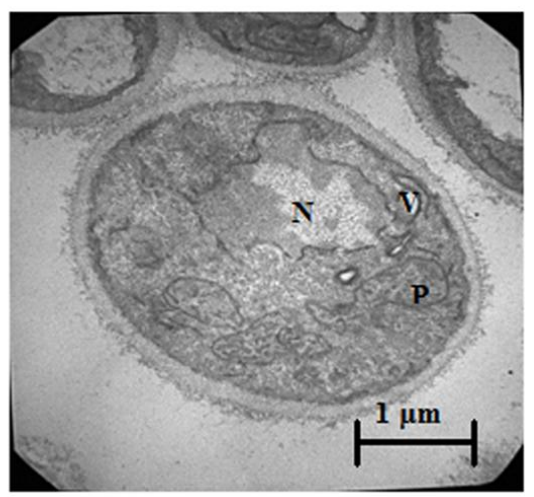

Figure 12: Characteristics of the Ag/AuNPs - cells of $3^{\text {rd }}$ generation (a) in comparison with control cells (b). Top fluorescent microscopy (duration - $665 \mathrm{~ms}$ ) and bottom - TEM images ( $\mathrm{P}$ - peroxisome; $\mathrm{N}$ - nucleus; $\mathrm{V}$ - vacuole).

\section{CONCLUSION}

For molecular imaging applications, a variety of NPs including magnetic NPs, semiconductor quantum dots, carbon nanotubes, gold NPs, and graphene-based nanomaterials have been investigated and are expected to play increasingly more important roles in preclinical/clinical research in the future [5].

In this paper we focused on the development of a new method of cellular imaging with fluorescent bi-metallic NPs of noble metals ( $\mathrm{Au} / \mathrm{Ag}$ and $\mathrm{Ag} / \mathrm{Au}$ ) synthesized by chemical reduction of the relevant ions. The bi-metallic colloids proved to possess the stable fluorescence (on green, red and blue channels) in solution (more than 2 months).

To develop the method of cell imaging, the recombinant yeast cells Hansenula polymorpha were used as the model of living organism. All NPs in minimal concentration (up to $0.05 \mathrm{mM}$ ) was proved to be non-toxic: under 3-day cultivation in liquid medium with NPs, yeast cells didn't affect significantly neither the dynamics of growth nor enzyme (arginase) activity.

We have demonstrated, that after penetration of fluorescent NPs through the cells membrane, the modified cells stay alive and fluorescent. Yeast cells of the $1^{\text {st }}$ generation, modified by fluorescent NPs, kept ability to grow on agar and liquid medium. The fluorescent NPs synthesized allow us to observe the phenomenon of transferring of fluorescent NPs from parental to daughter cells through at least three generations followed by releasing of NPs from the modified cells. So, the synthesized NPs being small, non-toxic and fluorescent, may be perspective tool for cell imaging in biomedical sciences and clinical diagnostics.

Thus, our findings might be eventually interesting for the fundamental and applied biological sciences, namely for the study of molecular mechanisms of cell protection from stress, caused by exposure to toxic compounds, particularly, to NPs as well as for the development of methods for the synthesis of nano-sized fluorescent labels for clinical diagnostics and testing.

\section{ACKNOWLEDGMENTS}

This work was financially supported by Individual grant of OPTEC company for young scientists (Stasyuk-2014), by NAS of Ukraine (in the frames of program "Sensors for Medical, Environmental, Industrial, and Technological Needs" and by NATO (Project CBP. NUKR.SFP 984173). 


\section{REFERENCES}

[1] Key, J., Leary J.F. 2014. Nanoparticles for multimodal in vivo imaging in nanomedicine. Int. J. Nanomedicine. 9, 711726.

[2] Boisselier, E., Astruc, D. 2009. Gold nanoparticles in nanomedicine: preparations, imaging, diagnostics, therapies and toxicity. Chem. Soc. Rev. 38, 1759-1782.

[3] Bao, G., Mitragotri, S., Tong, S. 2013. Multifunctional nanoparticles for drug delivery and molecular imaging. Annu Rev. Biomed. En. 15, 253-282.

[4] Kreuter, J. 2014. Nanoparticulate systems for brain delivery of drugs. Adv. Drug Deliv. Rev. 71, 2-14.

[5] Swierczewska, M., Lee, S., Chen, X. 2011. Inorganic nanoparticles for multimodal molecular imaging. Mol. Imaging. 10(1), 3-16.

[6] Zhu, Y., Hong, H., Xu, Z.P., Li, Z., Cai, W. 2013. Quantum dot-based nanoprobes for in vivo targeted imaging. Curr. Mol. Med. 13(10), 1549-1567.

[7] Gowda, R., Jones, N.R., Banerjee, S., Robertson, G.P. 2013. Use of nanotechnology to develop multi-drug ihibitors for cancer therapy. J. Nanomed. Nanotechnol. 4(6): doi:10.4172/2157-7439.1000184

[8] Guo, S., Wang, E. 2011. Noble metal nanomaterials : controllable synthesis and application in fuel cells and analytical sensors. Nano Today. 6, 240-264.

[9] You, H., Yang, S., Ding, B., Yang, H. 2013. Synthesis of colloidal metal and metal alloy nanoparticles for electrochemical energy applications. Chem. Soc. Rev. 42, 2880-2904.

[10] Mahmood Aliofkhazraei. 2014. Modern electrochemical methods in nano, surface and corrosion science. ISBN 978953-51-1586-1, 350 p, InTech, June 11, 2014 doi: 10.5772/57202.

[11] Garcia-Torres, J., Vallés, E., Gómez, E. 2010. Synthesis and characterization of Co@Ag core-shell nanoparticles. J. Nanopart. Res. 12, 2189-2199.

[12] Xue, C., Millstone, J.E., Li, S., Mirkin, C.A. 2007. Plasmon-driven synthesis of triangular core-shell nanoprisms from gold seeds. Angew. Chem. Int. Ed. 46, 8436-8439.

[13] Blosi, M., Albonetti, S., Ortelli, S., Costa, L. 2014. Green and easily scalable microwave synthesis of noble metal nanosols ( $\mathrm{Au}, \mathrm{Ag}, \mathrm{Cu}, \mathrm{Pd}$ ) usable as catalysts. New J. Chem. 38, 1401-1409.

[14] Zhao, J., Hu, W., Li, H., Ji, M., Zhao, C., Wanq, Z., Hu, H. 2015. One-step green synthesis of a ruthenium/graphene composite as a highly efficient catalyst. RSC Adv. 5, 7679-7686.

[15] Mittal, A.K., Chisti, Y., Banerjee. U.C. 2013. Synthes is of metallic nanoparticles using plant extracts. Biotechnology Advances. 31(2), 346-356.

[16] Nadagouda, M. N. 2012. Green synthes is of nanocrystals and nanocomposites. In: Kolesnikov N (ed) Modern aspects of bulk crystal and thin film preparation. InTech http://www.intechopen.com/books/modern-aspects-of-bulk-crystaland-thin-film-preparation/green-synthes is-of-nanocrys tals-and-nanocomposites .

[17] Bohren, C., Huffman, D. 1983. Absorption and scattering of light by small particles. Wiley, New York.

[18] Zhu, J., Wang, Y., Huang, L., Lu, Y. 2004. Resonance light scattering characters of core-shell structure of Au-Ag nanoparticles. Phys. Lett. A. 323, 455-459.

[19] Mulvaney, P., Giersig, M., Henglein, A. 1993. Electrochemistry of multilayer colloids: preparation and absorption spectrum of gold-coated silver particles. J Phys. Chem. 97, 7061-7064.

[20] Lee, A., Baddeley, C., Hardacre, C., Ormerod, R.M., Lambert, R.M., Schmid, G., West, H. 1995. Structural and catalytic properties of novel Au/Pd bimetallic colloid particles: EXAFS, XRD, and acetylene coupling. J. Phys. Chem. 99, 6096-6102.

[21] Knauer, A., Thete, A., Li, S., Romanus, H., Csáki, A., Fritzsche, W., Köhler, J. M. 2011. Au/Ag/Au double shell nanoparticles with narrow size distribution obtained by continuous micro segmented flow synthesis. Chem Eng $J$ 166:1164-1171.

[22] Yang, Y., Shi, J.L., Kawamura, G., Nogami. M. 2008. Preparation of Au-Ag, Ag-Au core-shell bimetallic nanoparticles for surface-enhanced Raman scattering. Scripta Mater. 58, 862-865.

[23] Rodriguez-Gonzalez, B., Burrows, A., Watanabe, M., Kiely, C.J., Liz Marzan, L.M. 2005. Multishell bimetallic AuAg nanoparticles: synthes is, structure and optical properties. J. Mater. Chem. 15, 1755-1759.

[24] Cao, Y.W., Jin, R., Mirkin, C.A. 2001. DNA-modified core-shell Ag/Au nanoparticles. J. Am. Chem. Soc. 123, 79617962.

[25] Rivas, L., Sanchez-Cortes, S., Garcia-Ramos, J.V., Morcillo, G. 2000. Mixed silver/gold colloids: a study of their formation, morphology, and surface-enhanced Raman activity. Langmuir. 16, 9722-9728. 
[26] Mohamed, M.B., Volkov, V., Link, S., El-Sayed, M.A. 2000. The lighting gold nanorods: fluorescence enhancement of over a million compared to the gold metal. Chem. Phys. Lett. 317, 517-523.

[27] Wilcoxon, J. P.; Martin, J. E.; Parsapour, F.; Wiedenman, B.; Kelley, D. F. 1998. Photoluminescence from Nanosize Gold Clusters. J. Chem. Phys. 108, 9137-9143.

[28] Jian, Z., Xiang, Z., Yongchang, W. 2005. Electrochemical synthesis and fluorescence spectrum properties of silver nanospheres. Microelectron. Eng. 77, 58-62.

[29] Mooradian, A. 1969. Photoluminescence of metals. Phys Rev Lett 22, 185-187.

[30] Liu, M., Guyot-Sionnest, P. 2004. Synthesis and optical characterization of Au/Ag core/shell nanorods. J. Phys. Chem. B. 108, 5882-5888.

[31] Zhang, L., Wang, E. 2014. Metal nanoclusters: new fluorescent probes for sensors and bioimaging. Nano Today._ 9, 132-157.

[32] Bamrungsap, S., Zhao, Z., Chen, T., Wang, L., Li, C., Fu, T., Tan, W. 2012. Nanotechnology in therapeutics: a focus on nanoparticles as a drug delivery system. Nanomedicine. 7, 1253-1271.

[33] Connor, E., Mwamuka, J., Gole, A., Murphy, C., Wyatt, M. 2005. Gold nanoparticles are taken up by human cells but do not cause acute cytotoxicity. Small. 1, 325-327.

[34] Sezer, A.D. Application of nanotechnology in drug delivery. ISBN 978-953-51-1628-8, 552 p. InTech, Chapters published July 25, 2014. DOI:10.5772/57028.

[35] Akhter, S., Ahmad, M.Z., Ahmad, F.J., Storm, G., Kok, R.J. 2012. Gold nanoparticles in theranostic oncology: current state-of-the-art. Expert. Opin. Drug Deliv. 9, 1225-1243.

[36] Lynch, I., Weiss, C., Valsami-Jones, E. 2014. A strategy for grouping of nanomaterials based on key physicochemical descriptors as a basis for safer-by-design NMs. Nano Today. 9, 266-270.

[37] Lemire, J.A., Harrison, J.J., Turner, R.J. 2013. Antimicrobial activity of metals: Mechanisms, molecular targets and applications. Nature reviews/Microbiology. 11, 371-384.

[38] Kuhn, D.A., Vanhecke, D., Michen, B., Blank, F., Gehr, P., Petri-Fink, A., Rothen-Rutishauser, B. 2014. Different endocytotic uptake mechanisms for nanoparticles in epithelial cells and macrophages. Beilstein J. Nanotechnol. 5, 1625-1636.

[39] Mironava, T., Hadjiargyrou, M., Simon. M., Jurukovski, V., Rafailovich, M.H. 2010. Gold nanoparticles cellular toxicity and recovery: Effect of size, concentration and exposure time. Nanotoxicology. 4, 120-137.

[40] Hoet, P.H., Nemery, B., Napierska, D. 2013. Intracellular oxidative stress caused by nanoparticles: What do we measure with the dichlorofluorescein assay? Nano Today. 8, 223-227.

[41] Wang, L., Clavero, C., Huba, Z., Carroll, E. E., Carpenter, D. Gu, Lukaszew, R. A. 2011. Plasmonics and enhanced magneto-optics in core-shell Co-Ag nanoparticles. Nano Lett 11:1237-1240

[42] Stasyuk, N., Serkiz, R., Mudry, S., Gayda, G., Zakalskiy, A., Koval'chuk, Y., Gonchar, M. 2011. Recombinant human arginase I immobilized on gold and silver nanoparticles: preparation and properties. Nanotechnology Development 1 , 11-15

[43] Synenka, M.M., Stasyuk, N.Ye., Semashko, T.V., Gayda, G.Z., Mikchailova, R.V., Gonchar M.V. 2014. Immobilization of oxidoreductases at gold and silver nanoparticles. Studia Biologica 8:5-16 (in Ukrainian).

[44] Stasyuk, N., Gayda, G., Gonchar, M. 2014. L-Arginine-selective microbial amperometric sensor based on recombinant yeast cells over-producing human liver arginase I. Sens Actuators B. 204, 515-521.

[45] Harriman, A. 1990. Bimetallic Pt-Au colloids as catalysts for photochemical dehydrogenation. J. Chem. Soc. Chem. Commun. 1, 24-26.

[46] Mallik, K., Mandal, M., Pradhan, N., Pal, T. 2001. Seed mediated formation of bimetallic nanoparticles by UV Irradiation: a photochemical approach for the preparation of "core-shell" type structures. Nano Lett. 1, 319-322

[47] Vodnik, V.V., Bozanic, D.K., Bibic, N., Šaponiić, Z.V., Nedeljković, J.M. 2008. Optical properties of shaped silver nanoparticles. J. Nanosci. Nanotechnol. 8,3511-3515.

[48] Cao-Milán, R., Liz-Marzán, L.M. 2014. Gold nanoparticle conjugates: recent advances toward clinical applications. Expert Opin. Drug Deliv. 11, 741-752 